\title{
KEMAMPUAN NUMERASI MAHASISWA PENDIDIKAN PROFESI GURU SEKOLAH DASAR DALAM MENYELESAIKAN MASALAH MATEMATIKA
}

\author{
Sri Hartatik ${ }^{1}$, Nafiah ${ }^{2}$ \\ ${ }^{1-2}$ Universitas Nahdlatul Ulama Surabaya \\ 'titax@unusa.ac.id, ${ }^{2}$ nefi_23@unusa.ac.id
}

\begin{abstract}
This research is a descriptive qualitative research that aims to describe how the numeracy ability of the 2019 Professional Teacher Education in Position in solving mathematical problems. The problems given were 2 problems. The research subjects were 31 Professional Teacher in Position Education students who were students who had worked as elementary school teachers spread across East Java and Madura. Numeration Ability is a focus on the ability of students to analyze, give reasons, and convey ideas effectively, formulate, solve, and interpret mathematical problems in various forms and situations (PISA). The results of this study were for question 1, the average numeracy ability of PPG SD students on the first indicator was 0.7 , the average numerical ability of students on the second indicator was 1.3 and the average value of student numeracy ability on the third indicator amounted to 1.37 . For question 2, the average numeracy ability of PPG elementary school students on the first indicator is 0.4 , the average numerical ability of students on the second indicator is 1 and the average value of student numeracy ability on the third indicator is 0.9 . The results of the analysis of the two questions, the lowest ability of PPG elementary school students in solving mathematical problems is the ability of students to use various numbers or symbols related to basic mathematics to solve problems in various contexts of daily life. Most PPG elementary school students make mistakes in writing numbers and symbols in solving mathematical problems even though the intention they want to convey is correct so that it will cause misconceptions for those who read the results of their problem solving.
\end{abstract}

Keywords: Numeration Ability, Mathematical Problems

\begin{abstract}
Abstrak:Penelitian ini merupakan penelitian kualitatatif deskriptif yang bertujuan untuk mendeskripsikan bagaimana kemampuan numerasi mahasiswa Pendidikan Profesi Guru Dalam Jabatan 2019 dalam menyelesaikan masalah matematika. Masalah yang diberikan sebanyak 2 soal. Subjek penelitian adalah mahasiswa Pendidikan Profesi Guru Dalam Jabatan sebanyak sebanyak 31 orang adalah mahasiswa yang sudah berkerja sebagai guru sekolah dasar yang tersebar di Jawa Timur dan Madura. Kemampuan Numerasi adalah fokus kepada kemampuan siswa dalam menganalisa, memberikan alasan, dan menyampaikan ide secara efektif, merumuskan, memecahkan, dan menginterpretasi masalah-masalah matematika dalam berbagai bentuk dan situasi Program for International Student Assessment (PISA) (PISA). Hasil dari penelitian ini adalah untuk soal 1, rata-rata kemampuan numerasi mahasiswa PPG SD pada indikator yang pertama sebesar 0,7, rata-rata kemampuan numerasi mahasiswa pada indikator kedua sebesar 1,3 dan nilai rata-rata kemampuan numerasi mahasiswa pada indikator ketiga sebesar 1,37. Untuk soal 2, rata-rata kemampuan numerasi mahasiswa PPG SD pada indikator yang pertama sebesar 0,4, rata-rata kemampuan numerasi mahasiswa pada indikator kedua sebesar 1 dan nilai rata-rata kemampuan numerasi mahasiswa pada indikator ketiga sebesar 0,9. Kesimpulannya dari kedua soal tersebut adalah, kemampuan terendah mahasiswa PPG SD daljab dalam menyelesaikan masalah matematika adalah kemampuan mereka dalam menggunakan simbol atau angka terkait matematika dalam menyelesaikan masalah sehari hari, hal itu disebabkan karena sebagian besar mahasiswa PPG SD banyak melakukan kesalahan dalam penulisan angka dan simbol dalam menyelesaikan masalah matematika padahal maksud yang ingin mereka sampaikan sudah benar sehingga akan menimbulkan miskonsepsi bagi yang membaca hasil penyelesaian masalah mereka.
\end{abstract}

Kata kunci: Kemampuan Numerasi, Masalah matematika 


\section{PENDAHULUAN}

Di dalam kehidupan bermasyarakat, banyak sekali informasi yang disajikan dalam berbagai simbol yang merupakan representasi dari informasi itu sendiri. Seperti informasi tentang rambu-rambu, iklan iklan yang berisi tentang informasi kesehatan, sosial, politik dan lainnya. Informasi-informasi yang disajikan biasanya disajikan dalam bentuk numerik maupun grafik. Kemampuan dalam membaca informasi yang berisikan numerik maupaun grafik sangat diperlukan untuk membuat keputusan yang tepat. Kemampuan numerasi berkontribusi yang nyata dalam kesejahteraan individu maupun masyarakat.Peningkatan kesejahteraan ekonomi dan daya saing ketenagakerjaan diperoleh dari kemampuan manusia dalam menggunakan matematika dalam konteks teknik, ekonomi maupun bidang lainnya.

Kemampuan numerasi siswa merupakan cerminan bagaimana proses pembelajaran numerasi di sekolah. Guru sekolah dasar harus mampu mengajarkan konsep numerasi mulai dari sekolah dasar. Dalam dunia pendidikan, kemampuan guru. Budaya literasi haruslah menyeluruh di seluruh rana pendidikan. Pada tahun 2016 melalui Kemendikbud meningkatkan Gerakan Literasi Nasional (GLN) yang merupakan bagian dari implementasi Permendikbud Nomor 23 Tahun 2015. Literasi numerasi merupakan salah satu bagian literasi di bidang matematika. Baik di perguruan tinggi maupun sekolah perlu meningkatkan kecakapan terkait literasi matematik dalam memperhitungkan tantangan abad 21(Orrill Robert, 2001). Sekolah yang menerapkan linus (literasi numerasi) memperoleh hasil yang positif terhadap kemampuan membaca, dan menulis siswa (Peng, C. F). Program LINUS harus diteruskan dengan dibantu oleh keluarga, masyarakat sehingga melahirkan generasi muda yang boleh membaca dan menulis dengan cepat, dan mampu menggunakan numerik dalam menyelesaikan masalah sehari-hari. .

Numerasi merupakan kemampuan / keahlihan seseorang dalam menggunakan angka untuk menyelesaikan dengan praktis berbagai masalah sehari hari (Cockroft dalam Goos Merrlyn, 2011). Hal tersebut sesuai dengan apa yang disampaikan Tim G.L N. ( 2017) bahwa pengetahuan dan kecakapan dalam menggunakan berbagai macam angka dan simbol yang terkait dengan matematika dasar untuk memecahkan masalah kehidupan sehari-hari, kemampuan menganalisis informasi yang ditampilkan dalam berbagai bentuk (grafik, tabel, bagan, dsb.). Kemampuan numerasi juga merupakan kemampuan untuk menggunakan interpretasi hasil analisis tersebut untuk memprediksi dan mengambil keputusan disebut dengan literasi numerasi. Literasi matematika juga dapat digunakan dalam menyelesaikan masalah yang tidak struktur (Mahmud, M. R., \& Pratiwi, I. M, 2019). Menurut Maulidina, A. P., \& Hartatik, S. (2019) siswa dengan kemampuan matematika tinggi mampu menggunakan berbagai macam angka atau simbol yang terkait matematika dasar untuk memecahkan masalah matematika, mampu menganalisis informasi dalam bentuk grafik, tabel, bagan dan lainnya dan menggunakan informasi tersebut dalam menyelesaikan masalah

Berdasarkan Hasil Programme for International Student Assessment ( PISA) untuk Indonesia tahun 2018, skor matematika dibawah rata-rata. Rata-rata skor PISA anggota OECD (The Organisation for Economic Co-operation and Development) untuk nilai matematika adalah 489 sedangkan nilai matematika Indonesia berada di kisaran nilai 375 . Jika dilihat dari beberapa tes PISA yang telah diikuti Indonesia sejak 2000, kemampuan literasi matematika mengalami penurunan., skor Indonesia di awal mengikuti tes PISA mencapai angka 371 dan mengalami peningkatan sebesar 382 di tahun 2003. Pada tahun 2006 skor Indonesia mencapai angka 393 dan di tahun 2009 mencapai skor 402, kemudian terus mengalami penurunan 396 di tahun 2012, 397 di tahun 2015 ( penurunan 1 angka dari tahun sebelumnya), dan titik terendah di tahun 2018 yaitu di poin 371 (Kompas.com, 2019). 
Peninggkatan kemampuan numerasi siswa harus di dukung sepenuhnya baik dari lingkungan sekolah, keluarga dan masyarakat. Menurut Anggo, M. (2011) Kemampuan intelektual siswa dalam memahami, merencanakan, melakukan dan memperoleh solusi dari berbagai masalah yang ada merupakan tujuan dari diberikan nya masalah matematika bagi siswa di sekolah.

Pendidikan profesi Guru Sekolah Dasar merupakan pendidikan yang mencetak guru profesional. Guru profesional merupakan guru yang menguasai 4 kompetensi yaitu kompetensi pedagogik, profesional, kepribadian dan sosial. Kompetensi profesional adalah kompetensi yang penguasaan materi pembelajaran SD yang meliputi matematika, bahasa Indonesia, PKN, IPS dan IPA. Kompetensi Profesional guru sekolah dasar adalah penguasaan materi pembelajaran dengan pembelajaran SD secara luas dan mendalam, yang mencakup penguasaan materi kurikulum mata pelajaran di sekolah dan substansi keilmuan dari materinya, serta penguasaan terhadap struktur dan metodologi keilmuannya,salah satunya kemampuan literasi dan numerasi. Untuk meningkatkan kemampuan numerasi siswa maka guru profesional harus mempunyai kemampuan numerasi yang baik pula.

\section{METODE}

Penelitian ini menggunakan metode penelitian deskriptif Kuantitatif yang ditujukan untuk mendeskripsikan data-data kuantitatif terkait kemampuan numerasi mahasiswa PPG dalam menyelesaikan masalah matematika. Ada 2 masalah matematika yang digunakan dalam penelitian ini yaitu untuk masalah yang pertama siswa diminta menentukan lamanya waktu dan masalah yang kedua, sesuai dengan pemahaman masing-masing siswa diminta untuk menganalisis 2 pernyataan ( gambar1):

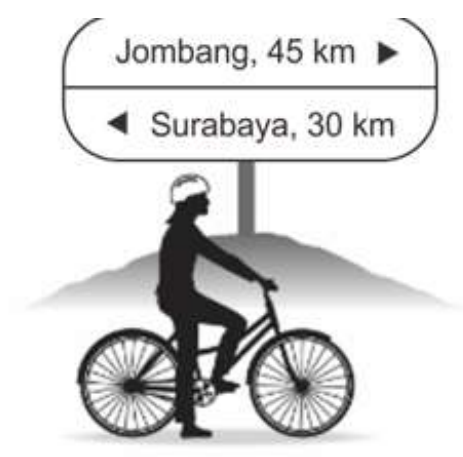

1. Perhatikan gambar diatas, Andi melanjutkan bersepeda dengan kecepatan yang sama menuj' Jombang. Berapa lama waktu yang dibutuhkan Andi dari tanda tersebut hingga Jombang?

2. Andi dan Budi sama-sama suka makan bakso Pak Eko. Andi makan bakso setiap 3 hari sekal Budi makan bakso setiap 4 hari sekali. Pada hari ini Andi dan Budi makan bakso bersama. Anc mengatakan kepada Budi, 2436 hari lagi kita akan makan bersama lagi di tempat ini. Buc mengatakan kepada Andi, 1020 hari lagi kita akan makan bersama lagi di tempat ini. Apaka. pemyataan Andi dan Budi benar? Jelaskan!

\section{Gambar 1 Instrumen Tes Pemecahan Masalah}

Intrumen tersebut diberikan kepada 30 mahasiswa PPG Unusa Tahap 1 yang merupakan sampel penelitian ini. Mereka di minta untuk menyelesaikan 2 soal yang diberikan dengan waktu 30 menit. Hasil pemecahan masalah yang telah dikerjakan mahasiswa kemudian di analisis berdasarkan indikator numerasi sebagai berikut 
Tabel 1. Penilaian Kemampuan Numerasi

\begin{tabular}{|c|c|c|c|c|}
\hline \multirow[t]{2}{*}{ No } & \multirow{2}{*}{$\begin{array}{c}\text { Indikator Numerasi } \\
\text { (Tim, G. L. N. 2017) }\end{array}$} & \multicolumn{3}{|c|}{ Penilaian } \\
\hline & & 2 & 1 & 0 \\
\hline 1 & $\begin{array}{l}\text { mampu menggunakan } \\
\text { berbagai macam angka } \\
\text { atau simbol yang } \\
\text { terkait dengan } \\
\text { matematika dasar } \\
\text { dalam menyelesaikan } \\
\text { masalah kehidupan } \\
\text { sehari-hari. }\end{array}$ & $\begin{array}{l}\text { mahasiswa mampu } \\
\text { menggunakan berbagai } \\
\text { macam angka atau } \\
\text { simbol yang terkait } \\
\text { dengan matematika } \\
\text { dasar dalam } \\
\text { menyelesaikan } \\
\text { masalah kehidupan } \\
\text { sehari-hari dengan } \\
\text { jawaban akhir benar. }\end{array}$ & $\begin{array}{l}\text { Mahasiswa cukup } \\
\text { mampu } \\
\text { menggunakan } \\
\text { berbagai macam } \\
\text { angka atau simbol } \\
\text { yang terkait dengan } \\
\text { matematika dasar } \\
\text { dalam } \\
\text { menyelesaikan } \\
\text { masalah kehidupan } \\
\text { sehari-hari dengan } \\
\text { jawaban akhir } \\
\text { benar. }\end{array}$ & $\begin{array}{l}\text { Mahasiswa belum } \\
\text { mampu } \\
\text { menggunakan } \\
\text { berbagai macam } \\
\text { angka atau simbol } \\
\text { yang terkait } \\
\text { dengan } \\
\text { matematika dasar } \\
\text { dalam } \\
\text { menyelesaikan } \\
\text { masalah } \\
\text { kehidupan sehari- } \\
\text { hari dan jawaban } \\
\text { akhir salah. }\end{array}$ \\
\hline 2 & $\begin{array}{l}\text { Mampu menganalisis } \\
\text { informasi yang } \\
\text { ditampilkan dalam } \\
\text { berbagai bentuk } \\
\text { (grafik, tabel, bagan, } \\
\text { diagram dan lain } \\
\text { sebagainya). }\end{array}$ & $\begin{array}{l}\text { Mahasiswa mampu } \\
\text { menganalisis informasi } \\
\text { yang ditampilkan } \\
\text { dalam berbagai bentuk } \\
\text { (grafik, tabel, bagan, } \\
\text { diagram dan lain } \\
\text { sebagainya). }\end{array}$ & $\begin{array}{l}\text { Mahasiswa cukup } \\
\text { mampu } \\
\text { menganalisis } \\
\text { informasi yang } \\
\text { ditampilkan dalam } \\
\text { berbagai bentuk } \\
\text { (grafik, tabel, } \\
\text { bagan, diagram dan } \\
\text { lain sebagainya). }\end{array}$ & $\begin{array}{l}\text { Mahasiswa belum } \\
\text { mampu } \\
\text { menganalisis } \\
\text { informasi yang } \\
\text { ditampilkan } \\
\text { dalam berbagai } \\
\text { bentuk (grafik, } \\
\text { tabel, bagan, } \\
\text { diagram dan lain } \\
\text { sebagainya).. }\end{array}$ \\
\hline 3 & $\begin{array}{l}\text { Menafsirkan hasil } \\
\text { analisis tersebut untuk } \\
\text { memprediksi dan } \\
\text { mengambil keputusan. }\end{array}$ & $\begin{array}{l}\text { Mampu menafsirkan } \\
\text { seluruh hasil analisis } \\
\text { tersebut untuk } \\
\text { memprediksi dan } \\
\text { mengambil keputusan } \\
\text { dengan tepat. }\end{array}$ & $\begin{array}{l}\text { Mampu } \\
\text { menafsirkan } \\
\text { sebagian hasil } \\
\text { analisis tersebut } \\
\text { untuk memprediksi } \\
\text { dan mengambil } \\
\text { keputusan dengan } \\
\text { tepat. }\end{array}$ & $\begin{array}{l}\text { Belum mampu } \\
\text { menafsirkan hasil } \\
\text { analisis tersebut } \\
\text { untuk } \\
\text { memprediksi dan } \\
\text { mengambil } \\
\text { keputusan dengan } \\
\text { tepat. }\end{array}$ \\
\hline
\end{tabular}

\section{HASIL}

Kemampuan numerasi dalam PISA (Programme for International Student Assessment) adalah fokus kepada kemampuan siswa dalam menganalisa, memberikan alasan, dan menyampaikan ide secara efektif, merumuskan, memecahkan, dan menginterpretasi masalah-masalah matematika dalam berbagai bentuk dan situasi. Berikut ini dipaparkan hasil analisa kemampuan numerasi mahasiswa PPG Daljab dalam menyelesaikan masalah Matematika

\section{Kemampuan numerasi mahasiswa PPG Daljab dalam menyelesaikan masalah pada soal 1.}

Diagram di bawah merupakan rekapan hasil pemecahan masalah TPM soal nomor 1 dari 30 mahasiswa PPG SD Daljab berdasarkan indikator numerasi adalah sebagai beri 


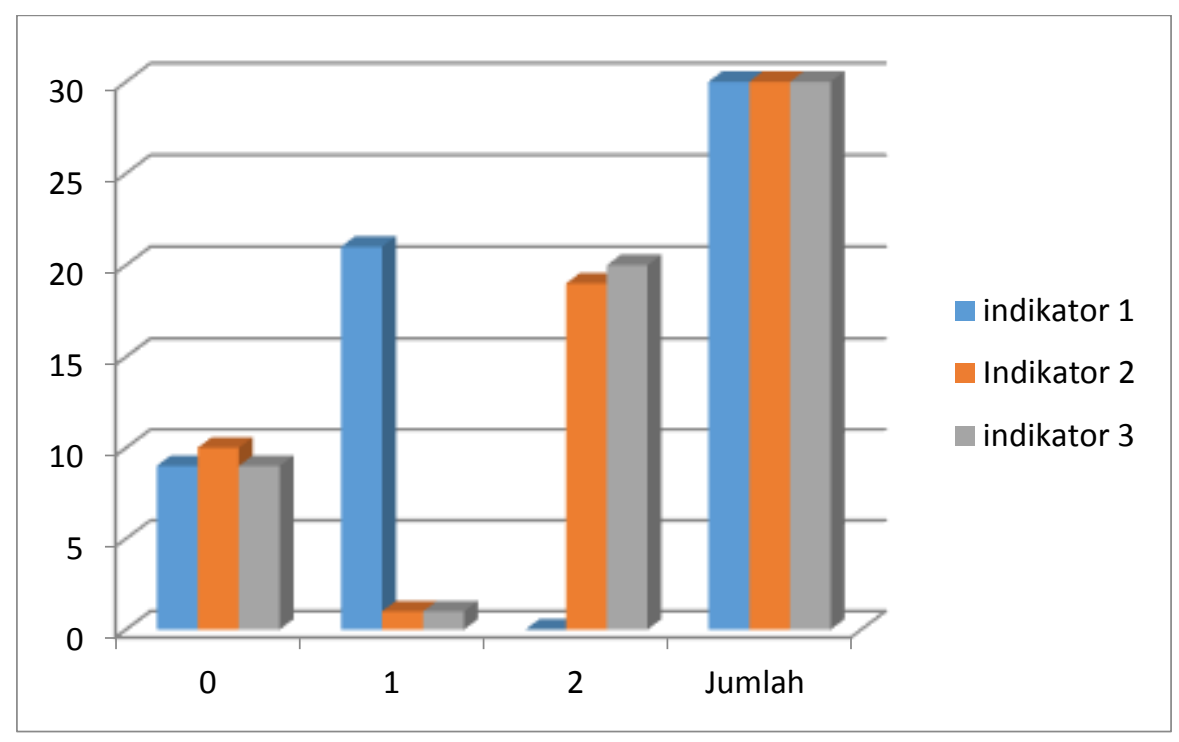

Gambar 2 diagram batang jumlah mahasiswa yang memperoleh nilai baik 2,1, maupun 0 pada soal 1.

Berdasarkan diagram batang di atas (Gambar 2), dapat dilihat pada indikator 1 yaitu batang yang berwarna biru menunjukkan terdapat sejumlah 21 mahasiswa dengan presentase $70 \%$ memporeh nilai 1 yang artinya kemampuan mahasiswa PPG SD Daljab dalam menggunakan berbagai macam angka atau simbol yang terkait dengan matematika dasar untuk memecahkan masalah dalam berbagai macam konteks kehidupan sehari-hari masih kurang tepat akan tetapi jawabannya sudah betul. Ada penempatan angka dan simbol yang kurang tepat sehingga maknanya pun juga kurang tepat. Sedangkan 9 mahasiswa PPG SD Daljab dengan presentase $30 \%$ memperoleh nilai 0 yang artinya belum mampu menggunakan berbagai macam angka atau simbol yang terkait dengan matematika dasar untuk memecahkan masalah dalam konteks kehidupan sehari-hari dan jawabannya salah.

Perhatikan diagram batang berwarna merah (Gambar 2) menunjukkan indikator ke2, yaitu terdapat sebanyak 19 mahasiswa dengan presentase $63 \%$ memeperoleh poin 2 yang artinya mereka mampu menganalisis informasi yang ditampilkan dalam berbagai bentuk seperti grafik, tabel, bagan, diagram dan lain sebagainya sehingga menghasilkan semua jawaban yang benar. Terdapat 1 mahasiswa dengan presentase 3,3\% yang mampu menganalisis informasi yang ditampilkan dalam berbagai bentuk seperti grafik, tabel, bagan, diagram dan lain sebagainya sehingga sebagian besar jawaban benar. Sedangkan 10 mahasiswa dengan presentase $33 \%$ belum mampu menganalisis informasi yang ditampilkan dalam berbagai bentuk seperti grafik, tabel, bagan, diagram dan lain sebagainya sehingga jawabannya salah.

Untuk indikator ke 3 (Gambar 2 batang yang berwarna abu-abu), terdapat sebanyak 20 mahasiswa dengan presentase $67 \%$ memperoleh nilai 2 yang artinya mahasiswa mampu menafsirkan seluruh hasil analisis tersebut untuk memprediksi dan mengambil keputusan dengan tepat, sebanyak 1 mahasiswa dengan presentase 3,3\% yang memperoleh nilai 1 yang artinya mahasiswa tersebut mampu menafsirkan sebagian hasil analisis tersebut untuk memprediksi dan mengambil keputusan dengan tepat. Sedangan 9 mahasiswa dengan presentase $30 \%$ yang artinya mahasiswa belum mampu menafsirkan hasil analisis tersebut untuk memprediksi dan mengambil keputusan dengan tepat. 
Dari hasil analisa tersebut dapat bisa ditentukan rata-rata setiap indikator seperti tampak pada diagram batang di bawah ini.

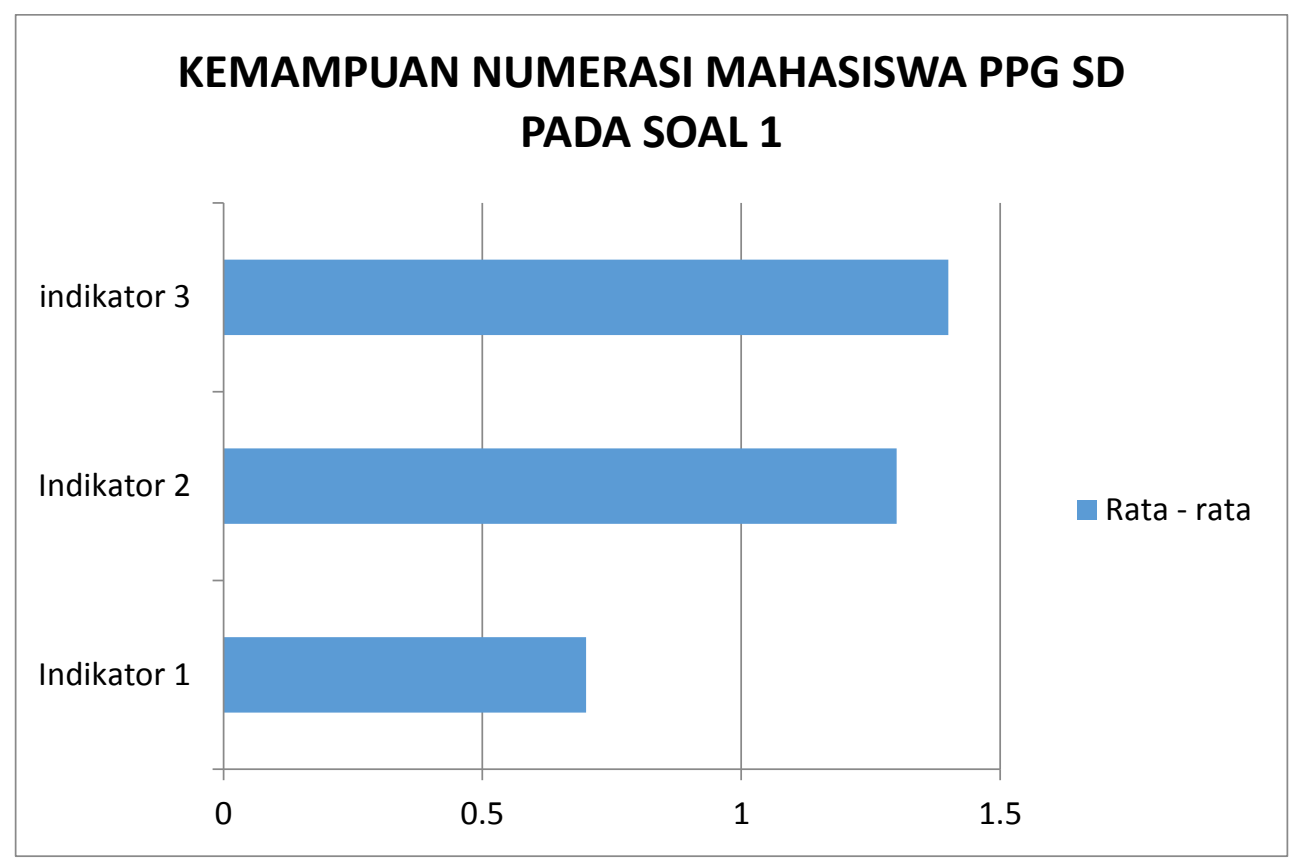

Gambar 4 Diagram batang rata-rata kemampuan numerasi pada soal 1

Berdasarkan gambar diagram di atas dapat diketahui rata-rata kemampuan numerasi mahasiswa PPG SD pada indikator yang pertama sebesar 0,7 , rata-rata kemampuan numerasi mahasiswa pada indikator kedua sebesar 1,3 dan nilai rata-rata kemampuan numerasi mahasiswa pada indikator ketiga sebesar 1,37. Berdasarkan nilai rata-rata tersebut di atas, nilai rata-rata tertinggi terdapat pada indikator ke 3 yaitu kemampuan mahasiswa dalam menafsirkan hasil analisis tersebut untuk memprediksi dan mengambil keputusan dengan benar. Sedangkan nilai rata-rata terendah terdapat pada indikator yang pertama yaitu kemampuan mahasiswa dalam menggunakan berbagai macam angka atau simbol yang terkait dengan matematika dasar untuk memecahkan masalah dalam berbagai macam konteks kehidupan sehari-hari. Sebagian besar mahasiswa PPG SD banyak melakukan kesalahan dalam penulisan angka dan simbol dalam menyelesaikan masalah matematika padahal maksud yang ingin mereka sampaikan sudah benar sehingga akan menimbulkan miskonsepsi bagi yang membaca hasil penyelesaian masalah mereka.

Kemampuan numerasi mahasiswa PPG Daljab dalam menyelesaikan masalah pada soal 2.

Diagram dibawah merupakan rekapan hasil pemecahan masalah TPM soal nomor 2 dari 30 mahasiswa PPG SD Daljab berdasarkan indikator numerasi adalah sebagai berikut. 


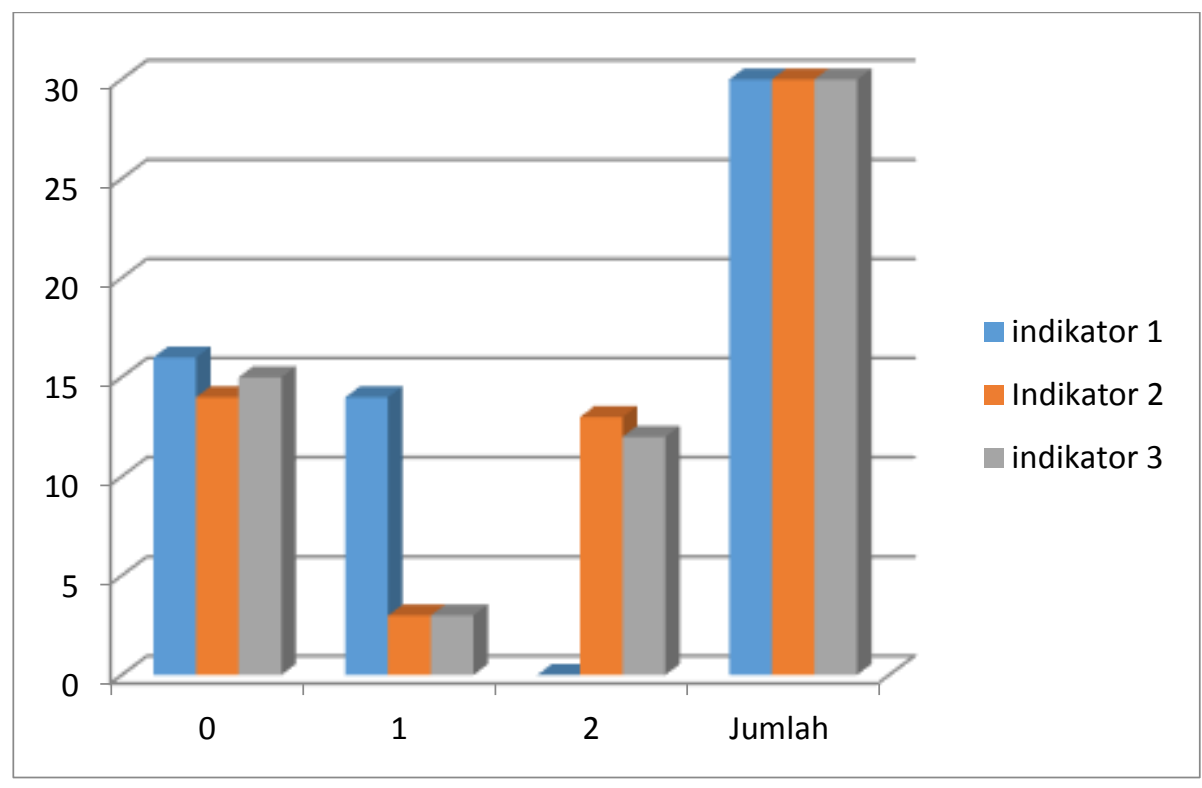

Gambar 5 diagram batang jumlah mahasiswa yang memperoleh nilai baik 2,1, maupun 0 pada soal 2.

Berdasarkan diagram batang di atas, pada indikator 1 (batang berwarna biru pada gambar 5) terdapat sejumlah 14 mahasiswa dengan presentase $47 \%$ memporeh nilai 1 yang artinya kemampuan mahasiswa PPG SD Daljab dalam menggunakan berbagai macam angka atau simbol yang terkait dengan matematika dasar untuk memecahkan masalah dalam berbagai macam konteks kehidupan sehari-hari masih kurang tepat akan tetapi jawabnnya sudah betul. Hal tersebut menyerupai seperti apa yang terjadi pada soal 1, ada penempatan angka dan simbol yang kurang tepat sehingga maknanya pun juga kurang tepat. Sedangkan 16 mahasiswa PPG SD Daljab dengan presentase $53 \%$ memperoleh nilai 0 yang artinya belum mampu menggunakan berbagai macam angka atau simbol yang terkait dengan matematika dasar untuk memecahkan masalah dalam konteks kehidupan sehari-hari dan jawabannya salah.

Perhatikan Gambar 5 batang yang berwarna merah untuk indikator yang kedua pada soal ke 2, terdapat sebanyak 13 mahasiswa dengan presentase $43 \%$ memeperoleh poin 2 yang artinya mereka mampu menganalisis informasi yang ditampilkan dalam berbagai bentuk seperti grafik, tabel, bagan, diagram dan lain sebagainya sehingga menghasilkan semua jawaban yang benar. Terdapat 3 mahasiswa dengan presentase $10 \%$ yang mampu menganalisis informasi yang ditampilkan dalam berbagai bentuk seperti grafik, tabel, bagan, diagram dan lain sebagainya sehingga sebagian besar jawaban benar. Sedangkan 14 mahasiswa dengan presentase $47 \%$ belum mampu menganalisis informasi yang ditampilkan dalam berbagai bentuk seperti grafik, tabel, bagan, diagram dan lain sebagainya sehingga jawabannya salah.

Untuk indikator ke 3 pada soal ke 2, sebanyak 12 mahasiswa dengan presentase 40 $\%$ memperoleh nilai 2 yang artinya mahasiswa mampu menafsirkan seluruh hasil analisis tersebut untuk memprediksi dan mengambil keputusan dengan tepat, sebanyak 3 mahasiswa dengan presentase $10 \%$ yang memperoleh nilai 1 yang artinya mahasiswa tersebut mampu menafsirkan sebagian hasil analisis tersebut untuk memprediksi dan mengambil keputusan dengan tepat. Sedangan 15 mahasiswa dengan presentase $50 \%$ yang artinya mahasiswa belum mampu menafsirkan hasil analisis tersebut untuk memprediksi dan mengambil keputusan dengan tepat. 
Dari hasil analisa tersebut dapat bisa ditentukan rata-rata setiap indikator seperti tampak pada diagram batang di bawah ini.

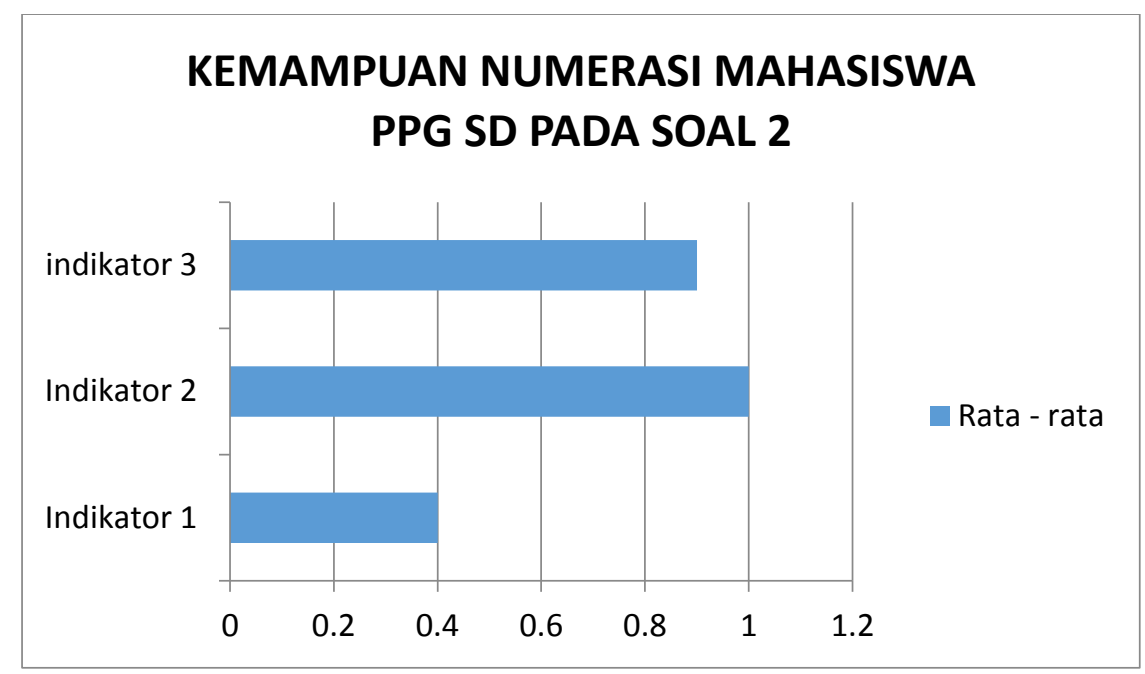

Gambar 6 Diagram batang rata-rata kemampuan numerasi pada soal 2

Berdasarkan gambar diagram di atas ( Gambar 6) dapat diketahui rata-rata kemampuan numerasi mahasiswa PPG SD pada indikator yang pertama sebesar 0,4 , ratarata kemampuan numerasi mahasiswa pada indikator kedua sebesar 1 dan nilai rata-rata kemampuan numerasi mahasiswa pada indikator ketiga sebesar 0,9. Berdasarkan nilai rata-rata tersebut diatas, nilai rata-rata tertinggi terdapat pada indikator ke 2 yaitu kemampuan mahasiswa dalam menganalisis informasi yang ditampilkan dalam berbagai bentuk (grafik, tabel, bagan, diagram dan lain sebagainya). Pada soal yang ke 2 informasi yang diberikan berupa kat-kata dan angka. Sedangkan nilai rata-rata terendah terdapat pada indikator yang pertama yaitu kemampuan mahasiswa dalam menggunakan berbagai macam angka atau simbol yang terkait dengan matematika dasar untuk memecahkan masalah dalam berbagai macam konteks kehidupan sehari-hari.

Hasil dari analisa kedua soal, kemampuan terendah mahasiswa PPG SD daljab dalam menyelesaikan masalah matematika adalah kemampuan siswa dalam menggunakan berbagai macam angka atau simbol yang terkait dengan matematika dasar untuk memecahkan masalah dalam berbagai macam konteks kehidupan sehari-hari. Sebagian besar mahasiswa PPG SD banyak melakukan kesalahan dalam penulisan angka dan simbol dalam menyelesaikan masalah matematika padahal maksud yang ingin mereka sampaikan sudah benar sehingga akan menimbulkan miskonsepsi bagi yang membaca hasil penyelesaian masalah mereka.

\section{PEMBAHASAN}

Berdasarkan analisis pemecahan masalah dari kedua soal yang diberikan dapat disimpulkan bahwa pada indikator yang pertama, untuk soal yang pertama terdapat petunjuk informasi dalam masalah berupa gambar dan simbol hasilnya sebanyak $70 \%$ mahasiswa kurang mampu menggunakan berbagai macam angka atau simbol yang terkait dengan matematika dasar untuk memecahkan masalah dalam konteks kehidupan sehari-hari artinya masih ada beberapa kesalahan dalam penggunakan simbol dalam proses menyelesaikan masalah yang diberikan. Artinya masih belum ada mahasiswa yang dengan tepat menggunakan simbol dan angka walaupun sebenarnya maksud yang ingin disampaikan 
adalah benar. Kesalahan dalam penempatan penggunaan simbol memag sering terjadi beberapa faktor penyebab kesalahan antara lain seperti yang disampaikan oleh Widodo,S.A(2013) kesalahan ada beberapa tahap yaitu kesalahan pada tahap pertama adalah kesalahan fakta, kesalahan karena kebiasaan, dan kesalahan intepretasi bahasa; kesalahan pada tahap kedua adalah kesalahan konsep dan fakta dan kesalahan pada tahap ketiga adalah kesalahan prinsip dan prosedur. Jika dilihat dari hasil penyelesaian masalah yang sudah dilakukan sebagai besar para mahasiswa melakukan kesalahan interpretasi bahasa simbol. Kesalahan interpretasi simbol dalam pembelajaran matematika bayak terjadi dikarenakan pengalaman belajar matematika dan belum bisa memaknai simbol secara keseluruhan hal ini dibuktikan juga oleh beberapa peneliti yang juga meneliti tentang miskonsepsi seperti Farida (2016) dan Matitaputty (2016). Sedangkan untuk $30 \%$ mahasiswa memang belum mampu menggunakan berbagai macam angka atau simbol yang terkait dengan matematika dasar untuk memecahkan masalah dalam konteks kehidupan sehari-hari dan jawaban akhirnya juga salah. Hal tersebut terjadi karena adanya kesalahan prinsip dan prosedur dalam penyelesaian masalah matematika. Sarlina (2015) mengungkapkan peenyebab umum dari miskonsepsi yaitu berasal dari siswa, guru / pengajar, buku teks, konteks, dan cara mengajar. Penyebab yang berasal dari siswa dapat terdiri dari berbagai hal, seperti prakonsepsi awal, kemampuan, tahap perkembangan, minatnya terhadap pelajaran matematika, cara berpikir dan teman lain. Guru dapat menyebabkan miskonsepesi berupa ketidakmampuan atau sikap guru dalam berelasi dengan siswa yang kurang baik, jarangnya konsep diajarkan di kelas, rendahnya keinginan dan minat siswa untuk belajar konsep dan menggunakan rumus.

Hasil analisis pada soal yang ke-dua sebanyak $40 \%$ mahasiswa yang kurang mampu menggunakan berbagai macam angka atau simbol yang terkait dengan matematika dasar untuk memecahkan masalah dalam konteks kehidupan sehari-hari walaupun hasilnya benar. Hal ini disebabkan adanya kesalahan dalam menggunakan simbol dalam proses menyelesaikan masalah matematika. Sedangkan $60 \%$ siswa siswa betul betul tidak mampu menggunakan simbol dan angka dalam penyelesaian masalah matematika hal ini bisa jadi disebabkan karena kesalahan dalam konsep. Ada beberapa faktor yang menyebabkan miskonsepsi terhadap pembelajaran matematika yaitu melalui pengalaman belajar yang dialami oleh masing-masing individu. Hal ini sejalan dengan apa yang disampaikan oleh Sarlina (2015) bahwa yang menjadi penyebab adanya miskonsepsi adalah jarangnya konsep diajarkan dikelas, rendahnya keinginan siswa untuk belajar konsepdan rumus, kurangnya pemanfatan alat peraga, media pembelajaran dan buku-buku, serta sering berpacu hanya dari satu sumber, yaitu LKS saja seperti yang disampaikan.

Kemampuan numerasi mahasiswa PPG SD pada indikator ke-2, untuk soal yang pertama 19 mahasiswa dengan presentase $63 \%$ dan pada soal ke 2 terdapat sebanyak 13 mahasiswa dengan presentase $43 \%$ memeperoleh poin 2 yang artinya mereka mampu menganalisis informasi yang ditampilkan dalam berbagai bentuk seperti grafik, tabel, bagan, diagram dan lain sebagainya sehingga menghasilkan semua jawaban yang benar artinya mereka mampu menganalisis informasi dalam bentuk tulisan / verbal dengan benar. Mahasiswa lebih mudah menganalisis informasi dalam bentuk gambar daripada kata-kata atau tulisan karena representasi matematik seperti gambar akan memudahkan siswa dalam menyelesaikan masalah matematika.Kemampuan menyajikan kembali notasi, simbol, tabel, gambar, grafik, diagram, persamaan atau ekspresi matematis lainnya ke dalam bentuk lain sehingga mempermudahkan dalam menerjemahkan masalah disebut dengan kemampuan representasi matematis (Lestari \& Yudhanegara, 2015). 
Kemampuan numerasi mahasiswa PPG SD pada indikator ke-3, untuk soal 1 terdapat sebanyak 20 mahasiswa dengan presentase $67 \%$ memperoleh nilai 2 yang artinya mahasiswa mampu menafsirkan seluruh hasil analisis tersebut untuk memprediksi dan mengambil keputusan dengan tepat, sedangkan untuk soal ke 2 terdapat 12 mahasiswa dengan presentase $40 \%$ memperoleh nilai 2 yang artinya mahasiswa mampu menafsirkan seluruh hasil analisis tersebut untuk memprediksi dan mengambil keputusan dengan tepat. Berdasarkan hasil paparan hasil penyelesaian pada ke dua soal tersebut dapat disimpulkan bahwa kemampuan numerasi mahasiswa PPG SD dalam menyelesaikan soal pertama lebih tinggi dari pada kemampuan numerasi mahasiswa PPG SD dalam menyelesaikan soal kedua. Hal itu dikarenakan pada soal yang pertama terdapat gambar yang dapat membantu pemahaman siswa terkat permasalahan yang diberikan.

\section{SIMPULAN DAN SARAN}

Berdasarkan hasil analisa data dapat disimpulkan bahwa rata-rata kemampuan numerasi mahasiswa PPG SD dalam jabatan dalam menyelesaikan matematika adalah : 1. Mahasiswa PPG Daljab kurang mampu menggunakan berbagai angka 2. Mahasiswa PPG Dalajab mampu menganalisis informasi dalam bentuk grafik, tabel dsb. 3.Mahasiswa PPG Daljab mampu mempredikasi dan mengambil keputusan. Hasil dari analisa kedua soal, kemampuan terendah mahasiswa PPG SD daljab dalam menyelesaikan masalah matematika adalah kemampuan mahasiswa dalam menggunakan berbagai macam angka atau simbol yang terkait dengan matematika dasar dalam menyelesaikan masalah kehidupan sehari-hari.. Sebagian besar mahasiswa PPG SD banyak melakukan kesalahan dalam penulisan angka dan simbol dalam menyelesaikan masalah matematika padahal maksud yang ingin mereka sampaikan sudah benar sehingga akan menimbulkan miskonsepsi bagi yang membaca hasil penyelesaian masalah mereka.

Penelitian ini masih perlu dikembangkan dan dilakukan penelitian lanjutan guna mengetahui tentang mahasiswa dalam menyelesaian masalah matematika.

\section{DAFTAR RUJUKAN}

Anggo, M. (2011). Pelibatan metakognisi dalam pemecahan masalah matematika. Edumatica: Jurnal Pendidikan Matematika.

Farida, A. (2016). Analisis miskonsepsi siswa terhadap simbol dan istilah matematika pada konsep hubungan bangun datar segiempat melalui permainan dengan alat peraga (SD Muhammadiyah 1 Surakarta).

Goos, M., Dole, S., \& Geiger, V. (2011). Improving Numeracy Education in Rural Schools: A Professional Development Approach. Mathematics Education Research Journal, 23(2), 129.

Kompas.com. 04/12/2019, 13:00 WIBSkor PISA Terbaru Indonesia, Ini 5 PR Besar Pendidikanpada Era Nadiem Makarim", https://edukasi.kompas.com/read/2019/12/04/13002801/skor-pisa-terbaruindonesia-ini-5-pr-besar-pendidikan-pada-era-nadiem-makarim?page=all.

Lestari, Eka Karunia., dan Yudhanegara, M. Ridwan, (2015), Penelitian Pendidikan Matematika, Bandung: PT. Refika Aditam

Mahmud, M. R., \& Pratiwi, I. M. (2019). LITERASI NUMERASI SISWA DALAM PEMECAHAN MASALAH TIDAK TERSTRUKTUR. Kalamatika: Jurnal 
Pendidikan Matematika, 4(1), 69-88.

DOI:https://doi.org/10.22236/KALAMATIKA.vol4no1.2019pp69-

88/http://kalamatika.matematika-uhamka.com/index.php/kmk/article/view/331

Maulidina, A. P., \& Hartatik, S. (2019). PROFIL KEMAMPUAN NUMERASI SISWA SEKOLAH DASAR BERKEMAMPUAN TINGGI DALAM MEMECAHKAN MASALAH MATEMATIKA. Jurnal Bidang Pendidikan Dasar, 3(2), 61-66. https://doi.org/10.21067/jbpd.v3i2.3408/ejournal.unikama.ac.id/index.php/JBPD/a rticle/view/3408

Matitaputy, C. (2016). Miskonsepsi Siswa dalam Memahami Konsep Nilai Tempat Bilangan Dua Angka. Mosharafa: Jurnal Pendidikan Matematika, 5(2), 113-119

Peng, C. F. (2016). PELAKSANAAN PROGRAM LITERASI DAN NUMERASI (LINUS) DI SEKOLAH RENDAH (The Implementation of Literacy and Numeracy (LINUS) Program at Primary School). Jurnal Pendidikan Bahasa Melayu, 5(2), 1-11.

Robert Orrill. (2003). Quantitative Literacy: Why Numeracy Matters for Schools and Colleges. Princeton: National Council on Education and the Disciplines.

Sarlina, S. (2015). Miskonsepsi Siswa Terhadap Pemahaman Konsep Matematika Pada Pokok Bahasan Persamaan Kuadrat Siswa Kelas X5 Sma Negeri 11 Makassar. MaPan: Jurnal Matematika dan Pembelajaran, 3(2), 194-209. DOI: https://doi.org/10.24252/mapan.2015v3n2a5

Tim, G. L. N. (2017). Materi Pendukung Literasi Numerasi Gerakan Literasi Nasional. Jakarta: Kemendikbud.

Widodo, S. A. (2013). Analisis kesalahan dalam pemecahan masalah divergensi tipe membuktikan pada mahasiswa matematika. Jurnal pendidikan dan pengajaran, 46(2 Juli).DOI: http://dx.doi.org/10.23887/jppundiksha.v46i2\%20Juli.2663 / https://ejournal.undiksha.ac.id/index.php/JPP/article/view/2663 